\title{
The Features of German Think Tanks Development and Their Interactions with the Authorities
}

\author{
Ihor Petrenko \\ Doctor of Political Sciences, Associate Professor, Taras Shevchenko National University of \\ Kyiv (Kyiv, Ukraine) \\ E-mail: i.petrenko.knu@gmail.com \\ https://orcid.org/0000-0003-3328-4102
}

Petrenko, Ihor (2019) The Features of German Think Tanks Development and Their Interactions with the Authorities. Ukrainian Policymaker, Volume 5, 61-67. https://doi. org/10.29202/up/5/7

The features of the German think tanks development and their interaction with the authorities are analyzed in the article. The typologization of German think tanks, in particular by such criteria as: type of activity (general or specialty), place of operation (open at universities, at foundations and as separate institutions), by scientific orientation (practical, fundamental), by sources of funding (funded by government, land or individuals) is carried out.

It is determined that the basis of German think tanks are political foundations - institutions unique in terms of organizational, legal and political form, which have no analogues in the world either in terms of the effectiveness of domestic political work or the scale of their presence abroad. Since their inception, these funds have belonged to one party or another, but they are now independent non-governmental organizations. In Germany, think tanks are effective and proven instruments of foreign and domestic policy. They complement the public policy of the state, and in some cases even implement (or promote) it in areas where the state is powerless. As non-governmental organizations, they may be involved in areas that are not accessible to official government.

It is established that academic think tanks and centers in Germany have a broad list of areas of activity and have an equal (average) impact on the political process. Depending on the transition from the first to the second and third stages, the influence of the contract centers is amplified and reaches its maximum at the stage of implementation of political decisions. Public interest protection centers and party think tanks, by contrast, are most influential in the first stage - the formulation of problems and the agenda for public policy. Thus, with the increase of the autonomy of the analytical communities, the opportunities for influencing the first stage of the political process increase, when, in fact, interests are taken into account on the agenda and alternative solutions of political problems are laid down.

Keywords: public policy, political decision, think tanks, political consultancy, political analysis

Received: November 26, 2019; accepted: December 10, 2019

(C) Petrenko, Ihor, 2019 


\section{Introduction}

There is no doubt that think tanks are a powerful foundation for improving the efficiency and optimality of public decision-makers. Having proven effective in the United States, think tanks have become an integral part of the political system of many countries, especially those seeking to play an important role in the world arena. The political, economic, historical and cultural diversity of European countries also determines the diversity of think tanks, which in each country have both their own characteristics and common features.

Russian researchers O. Balayan and O. Sungurov notes that the development of think tanks on the European continent was determined by the specifics of domestic political development. In view of this, the researchers conditionally distinguish two stages of the development of expert structures in Europe (Balayan \& Sungurov, 2016: 54-55):

1. Institutionalization with the support of the state of expert-analytical structures in England, Germany and France in the early twentieth century. This development can be explained that in Europe at that time there were no natural, evolutionary tendencies of development of think tanks, as opposed to the USA. In Western Europe, such structures were initially perceived as a negative and even potentially dangerous element of the political system. Also, the development of think tanks in Western Europe has been influenced by the ideological conflict between liberal and conservative ideological paradigms, and as a consequence, the long-term formation of the conservative tradition. It was autocratic, so it did not involve plural groups in the expert environment. Under such conditions, the formation of independent expert structures at that time was impossible. Analytical life was concentrated, for the most part, in universities.

2. The post-war period. The left ideological paradigm, which also did not involve the strengthening of expert structures dominated in Europe that time.

Another factor is the formation of truly independent think tanks in Europe in the 1970s. There were re-evaluation of the values in the layers of the intellectual elite and searching for new forms of interaction with the state.

Among Western European countries, for the analysis of think tanks, let us pay attention to Germany, because in this country were created unique institutions from an organizational, legal and political point of view, which have no analogues in the world either in terms of the effectiveness of internal political work or the scale of their presence abroad.

\section{Research Methodology}

The main methods of the research are systematic, historical, structural-functional, comparative, dichotomization and ideally-typical approach. The systematic method made it possible to consider German think tanks as a part of the country's political system. The historical method made it possible to analyze the formation and development of think tanks in Germany, as well as to clarify the patterns and conditions of their occurrence. Structural and functional method allowed to reveal the system components of the subject of study, to determine the main characteristics, types and functions of think tanks in Germany. The comparative method made it possible to compare the principles of activity of different types of think tanks in Germany, to establish general signs of influence of these institutions on the 
process of public policy formation in this country. Dichotomization methods and an ideallytypical approach were used to classify German think tanks.

\section{Research results}

In Germany, state structures have traditionally dominated in the preparation and discussion of proposed policy decisions. After World War II, there was a tendency in the country to develop think tanks from serving the interests of the state apparatus to focusing on broad public support. For a long time in Germany, expert-analytical consulting was entirely under the control of individual ministries and agencies. Academic studies were used mainly to legitimize government decisions in parliament. The public, the media and interest groups have rarely been involved in such discussions.

In the 1970s, the situation has changed. The number and complexity of the political issues raised before the government revealed the limitations of such a system. Parliament introduced the practice of public hearings and actively engaged experts in discussing issues of public importance for policymaking. Setting the agenda has ceased to be the prerogative of the government and parliamentary majority leaders. Relations between political experts and analysts with decisionmakers have become closer, and public dialogue has been more thorough.

It should also be noted that German society became more actively involved in the political life of the country, which also contributed to the development of think tanks. The activities of the state, relations between the state and society, the process of making important statepolitical decisions were in the field of view of more people. Accordingly, the understanding of public policy and the place of analytical institutions in it has changed.

The radical political and economic changes in the end of 1980s and early of 1990s increased the demand for expert and analytical activities. There were qualitative changes in the work of think tanks as they were forced to rebuild their analytical tools to study multipolar foreign policy, new security conditions, and changes in the post-Cold War world.

The Federal Republic of Germany and the German Democratic Republic reunification led to changes in the think tanks. They become interested in the countries of Eastern Europe and to carry out academic exchanges of information on democratic procedures and institutions. (Fillipov, 2007: 23-24).

According to D. Zvyagina, in Germany there are a large number of think tanks such as "universities without students", the main activity of which is scientific research. This category encompasses institutes investigating foreign policy, peace and security, such as the Institute of International Affairs and Security (The German Institute for International and Security Affairs, Stiftung Wissenschaft und Politik - SWP) (The German Institute, 2019) and the German Council on Foreign Relations (German Councilon Foreign Relations, Deutsche Gesellschaftfür Auswärtige Politik — DGAP) (German Council, 2019).

These think tanks study both international and intra-European issues. Thus, SWP examines issues of European integration, EU external relations and security policy, and DGAP is working on analysis of Franco-German relations as well as the political situation in Central and Eastern Europe. Unlike SWP, whose main mission is to make recommendations to the federal government, DGAP is an independent and non-partisan organization. The German Institute for Economic Research in Berlin (DIW) (German Institute, 2019), Institute for Economic Research at the University of Munich (IFO) (Leibniz Institute, 2019a), Kiel Institute of World Economics (IfW) (The Leibniz Institute, 2019), Rhine-Westphalia Institute for Economic 
Research (RWI) (Leibniz Institute, 2019), Halle Institute for Economic Research (IWH) (The Halle, 2019), German Institute of Business in Cologne (IW) (The German Economic, 2019) can also be included in this group of German think tanks. Their academic research is focused mostly on the economic aspects of European integration, as well as the prospects for the development of the EU from the point of view of the German economy (Zvyagina, 2014).

Let us consider the work of the German Institute for International Politics and Security (Science and Policy Foundation, SWP) as a reflection of the activities of "Universities without Students". It is an independent scientific institution that advises the German Bundestag and the Federal Government, using its own foreign policy and security studies. SWP was founded in 1962 on a private initiative. It is the country's largest think tank in this field and is an important information center for all foreign observers interested in discussions on German foreign policy.

The Institute carries out research work on many topics, in particular: European integration; common foreign and security policy; global security issues; studies of various countries and their foreign policy: America, countries of the former socialist camp, the Middle East and Africa, Asia - their participation in world affairs; global issues. The Institute's publications can be found in the monthly Journal "Internationale Politik", published in German, English, Russian and Chinese.

In the 1990s, some institutes created research unions at universities, like the Center for European Economic Research (ZEW), the Center for Applied Policy Studies (CAP), and the Center for European Integration Studies (ZEI).

A distinctive feature of German think tanks is their proximity to parties. For example, the Friedrich Ebert Foundation (Friedrich Ebert Stiftung), which was founded in 1925, is affiliated with the Social Democratic Party of Germany. The Foundation has offices in more than 100 countries, which shows that its level of influence is remarkable. The main purpose of the fund is to promote the political and social education of people of all walks of life in the spirit of democracy and pluralism. In addition to financial support, the fund organizes annual political seminars and conferences (Heineman et al., 2001: 114). The main directions of its work: 1) study of economic and social policy; 2) research on democracy and civil society; 3) Foreign Policy and Security (Friedrich, 2019).

Another well-known think tank in Germany is The Conrad Adenauer Foundation (Konrad Adenauer Stiftung), which was created in 1955 and affiliated with the center-right Christian Democratic Union. The Foundation has offices and implements various programs in 100 countries. Its purpose is education, the promotion of freedom, peace and justice, the improvement of transatlantic relations and the deepening of cooperation for the development of Europe. The main directions of the Fund's work: 1) the development of democracy in the modern world; 2) economic problems of the modern world; 3 ) development of the state and civil society.

Today the Foundation has 67 offices worldwide, with over 200 projects in 120 countries. This think tank is active throughout Germany and has two large training and teaching centers, 21 educational centers. The Fund develops scientific principles and modern methods of analysis that help to properly apply the German leadership and the CDU all political influence (Konrad, 2019).

So, another group of think tanks in Germany is the political foundations or the "Stiftungen", which MartinThunert calls unique and states that nothing else can be found in other countries except Austria, the Netherlands and, to a lesser extent, France (Thunert, 2000: 191-212). These political foundations include Friedrich-Ebert-Stiftung, the Konrad-Adenauer-Stiftung, Heinrich-Bell-Stiftung, Rosa Luxemburg-Stiftung. These funds are actively involved in 
foreign affairs. For example, promoting democracy in Africa and Latin America has been one of their main focuses. These organizations can only be called think tanks because they spend no more than $20 \%$ of their time on research. Fully funded by the state budget and closely linked to political parties represented in the Bundestag, they still retain some autonomy (Thunert, 2006: 185-221).

The international work of political foundations is carried out in two main directions: 1) implementation of short-term and long-term projects and local state programs - such work is coordinated by a regional office or a separate fund and usually involves organizational activities, establishing contacts and cooperation with partners, conducting various educational activities (conferences, round tables, meetings, seminars, trainings); 2) political analytics and research, publishing.

In general, think tanks in Germany can be typologized by several criteria.

First, by type of activity - general or special purpose. General think tanks (e.g. Institute for International Affairs and Security (SWP), German International Relations Council (DGAP), Center for Applied Political Studies in Munich (CAP) (The Center, 2019), The Bertelsmann Foundation (The Bertelsmann Foundation, 2019) conducts policy-oriented research at the intersection of such areas as relevant politics, business, science and the media. Their focus is on transatlantic relations, European integration, international security policy, energy policy, global economy and more.

Special-purpose think tanks focus on the study of a specific area of international relations or cooperation. Their two main areas of research are: 1) Peace and Security Problems The Peace Research Institute in Frankfurt (PRIF) (The Peace, 2019), Institute for Peace and Security Studies (ISFH) (The Institute, 2019), Bonn International Center for Transformation (Bonn, 2019); 2) economic research - the Kiel Institute for World Economy (IFW), the Rhine-Westphalia Institute for Economic Research (RWI) and more.

By the place of functioning, the think tanks are open: 1) at universities; 2) at funds; 3) as separate institutions.

Based on scientific orientation, the analytical centers are directed: 1) on practice; 2) on basic research. Most of them seek to combine these areas and combine international and interdisciplinary analysis with specific proposals to improve existing practices.

By the sources of funds, the analytical centers are divided into: 1) federal funds; 2) funded by the state (the federal government); 3) which are financially supported by individuals (donations) (Zvyagina, 2014).

According to researchers from the Humanitarian Technology Agency, German think tanks are in a difficult situation, they are overwhelmed by the complex and large-scale tasks that modern Germany is solving. Researchers notice changes in the activities of German think tanks. They have several major trends: 1) the process of integration of Europe and its impact on the social and political life of Germany; 2) deduction of large funds for democratization of Eastern European states; 3 ) maintaining the integrity of the EU and overcoming permanent crises in it (Modern think tanks: an analytical report of the Center for Humanitarian Technologies, 1998).

German think tanks work closely with the media. The centers offer a wide range of products of their scientific activity: they publish books, analytical notes and participate in joint research, conduct seminars, conferences, meetings. Presentation of the centers in the media and public life helps them in attracting sponsors and partners. When it comes to the target audience of German think tanks, it should be noted that, although politicians are the main recipients of their recommendations and research findings, they have successfully extended their influence 
to other spheres of society. German think tanks also attract the attention of diplomatic missions in other countries (Zvyagina, 2014).

According to MartinThunert, there are quite powerful academic institutes and university think tanks, traditions of state funding of analytical research and development in Germany. Charity and philanthropy are not well developed, informal contacts in the triangle "academics analysts - political elites" prevail over formal ones, while the "revolving door system" is a little popular. There are also problems of lack of political, strategic, applied, rather than academic research, and the need to be audit-oriented, to work on the boundaries of political and political \& cultural, political \& political; there is a tendency for science to hide the position and specific recommendations (Thunert, 2004: 71-88).

Martin Thunert also gives an assessment of the political impact of the German think tanks by their types and main functions. Academic think tanks mediate the formulation of problems and agendas for public policy, the choice of political action strategies, and the implementation of policy decisions. Contract think tanks have insufficient influence on the formulation of problems and agendas for public policy, the choice of political action strategies, and the powerful - on the implementation of political decisions. The effective involvement of public interest centers in shaping public policy issues and agendas is low in the choice of policy strategies. They almost have no effect on the implementation of political decisions. Party think tanks have a significant influence on the formulation of problems and the agenda for public policy, the average - on the choice of political action strategies and the implementation of political decisions (Thunert, 2004: 85).

Thus, academic think tanks in German have a broad list of activities and have an equal (average) impact on the political process. Depending on the transition from the first to the second and third stages, the influence of the contract centers is amplified and reaches its maximum at the stage of implementation of political decisions. Public interest protection centers and party think tanks, by contrast, are most influential in the first stage — the formulation of problems and the agenda for public policy. Thus, with the increase of the autonomy of the analytical communities, the opportunities for influencing the first stage of the political process increase, when, in fact, interests are taken into account on the agenda and alternative solutions of political problems are laid down.

\section{Conclusions}

The basis of German think tanks are political foundations, which are unique institutions from an organizational, legal and political point of view, that have no analogues in the world either in terms of the effectiveness of domestic political work or the scale of their presence abroad. These funds have, since their inception, belonged to one party or another, but now they are independent NGOs. According to the decision of the Constitutional Court, they have the right to receive funds from the federal budget, and sometimes, in the case of long-term projects, they can be funded by the German Foreign Ministry or the Ministry of Economic Cooperation and Development.

Think tanks in Germany are effective and verified factors of foreign and domestic policy. They complement the public policy of the state, sometimes even implementing (or promoting) it in areas where the state is powerless. Think tanks have such opportunities because of their unique place in the German political system. As non-governmental organizations, they may be involved in areas that are not accessible to official authorities. 


\section{References}

Balayan, A., Sungurov, A. (2016) Think tanks and expert societies. St. Petersburg: Alatheya. Modern think tanks: an analytical report of the Center for Humanitarian Technologies. ed. S. Datsuk. http://www.uis.kiev.ua/discussion/think_tanks.html.

Bonn International Center for Conversion (2019) https://www.bicc.de

Fillipov, V.A. (2007) Think tanks - Strategic Intelligent Resource. Moscow: LENAND.

Friedrich Ebert Stiftung (2019) https://www.fes.de/de/

German Council on Foreign Relations (Deutsche Gesellschaftfür Auswärtige Politik DGAP) (2019). https://dgap.org/en

German Institute for Economic Research (Deutsches Institutfür Wirtschaftsforschung — DIW) (2019). https://www.diw.de/en

Heineman, Robert A., Bluhm, WilliamT., Peterson, Steven A., and Kearny, Edward N. (2001)

The World of Policy Analyst Rationality, Values, and Politics. N-Y.

Konrad Adenauer Stiftung (2019) https://www.iiss.org

Leibniz Institute for Economic Research (formerly Rheinisch-Westfälisches Institut für Wirtsch aftsforschung — RWI) (2019). http://en.rwi-essen.de/das-rwi/

Leibniz Institute for Economic Research at the University of Munich (Leibniz Institut für Wirtschaftsforschung an der Universität München — IFO) (2019a). https://www. cesifo-group.de/ifoHome/CESifo-Group/ifo.html

The Bertelsmann Foundation (2019) http://www.bfna.org

The Center for Applied Policy Research (Centrum fürangewandte Politikforschung - CAP) (2019)http://www.cap-lmu.de/english/

The German Economic Institute (Institut der deutschen Wirtschaft - IW) (2019) https:// www.iwkoeln.de/en/

The German Institute for International and Security Affairs (Stiftung Wissenschaft und Politik) (2019) https://www.swp-berlin.org/en/

The Halle Institute for Economic Research (Das Leibniz-Institutfür Wirtschaftsforschung Halle - IWH) (2019) http://www.iwh-halle.de/en/

The Institute for Solar Energy Research in Hamelin (2019) http://www.isfh.de/?dm=1\&_l=1

The Leibniz Institute for Solid State and Materials Research Dresden (Das Leibniz-Institutfür Festkörper-und Werkstoffforschung Dresden — IFW) (2019). https://www.ifwdresden.de

The Peace Research Institute Frankfurt The Policy Studies Institute (2019) https://www.hsfk. de/index.php?L=1

Thunert, Martin (2000) Players Beyond Borders? German Think Tanks as Catalysts of Transnationalisation. Global Society. April. No. 2. P. 191-212.

Thunert, Martin (2004) Think tanks in Germany. eds. D. Stone, A. Denham. Think Tank Traditions: Policy Research and the Politics of Ideas. Manchester: University Press, P. 71-88.

Thunert, Martin (2006) The Development and Significance of Think Tanks in Germany. German Policy Studies. No 3. P. 185-221.

Zvyagina, D.A. (2014) Think tanks of Germany: success story. Contemporary scientific research and innovation. No 9. Part 2. http://web.snauka.ru/issues/2014/09/37292. 